\title{
Social Capital and Success of Minority Entrepreneurs
}

\author{
Michael Blanchett \\ University of Central Arkansas
}

\author{
Alexander Chen \\ University of Central Arkansas
}

Michael J. Rubach

University of Central Arkansas

\author{
Ron Duggins \\ University of Central Arkansas
}

\begin{abstract}
Scholars and policymakers can use this research to understand the relationship between successful performance of minority entrepreneurs and social capital. Entrepreneurship is a driving force that can create a society of self-supporting individuals. Minority entrepreneurship is an avenue for individuals to lift themselves out of poverty and create job opportunities for others. Social capital is economic and social networks used by people to promote transactions and alliances as a means to produce goods and services for themselves and for a common good. Social capital involves networking and political and social skills. Social capital networks consist of operations that include mutual benefits, trust, and cooperation. A quantitative analysis was conducted of a sample that included 287 minority male and female business owners to measure business revenues, company size, and self-reported assessment. The findings noted political and social skills significantly impact internal or intrinsic success measure. However, social networking did not relate to external or extrinsic success (revenue and size of company) among minorities in this study. Explanations are included about the findings and future research suggestions are also provided.
\end{abstract}

Keywords: Entrepreneurship, Interpersonal Skills, Minority Entrepreneurs, Political Skills, Social Capital

\section{INTRODUCTION}

Entrepreneurs have been vital contributors to local, state, and national economies (Decker, Haltiwanger, Jarmin, \& Miranda, 2014; Arthur \& Hisrich, 2011). During the 21st century, economic growth of the U.S. has stemmed largely from entrepreneurship. It is the driving force that creates a society of self-supporting individuals and a growing economy (Strom, 2007). Entrepreneurship may well be the primary avenue for individuals to improve themselves and create job opportunities for others (Bates, 
Jackson \& Johnson, 2007). What are the causes of this entrepreneurial success? Social capital, those networks created by entrepreneurs, has been identified as a major factor in the success of entrepreneurs. Is this true for all entrepreneurs? This study examines the social capital of minority entrepreneurs in Arkansas and whether its presence affects their success.

Entrepreneurship is a vital part of economies at all levels, from small local cities to state and national levels. In terms of economic impact, entrepreneurship is viewed as one of the most important components of economic activity and is moving to the forefront of the strategies employed to promote and encourage long-term economic development (Wennekers \& Thurik, 1999; Zoltan, Sameeksha, \& Jolanda, 2008). The gains and achievements with respect to minority entrepreneurs have contributed to numerous job creations. The efforts of minority entrepreneurs are increasing the number of minorities as economic contributors through the means of wealth creation. Though entrepreneurship is recognized as a powerful force and minority entrepreneurs have played a role in economic growth, the contribution of minorities remains relatively small. There is a need and opportunity to increase the success of minority entrepreneurs.

According to the U.S. Small Business Administration, minorities are more likely to be employees rather than business owners (SBA, 2015). It is recognized that the likelihood of being self-employed is substantially greater when one's parents were also self-employed (Lentz \& Laband, 1990; Fairlie \& Robb, 2007; Dunn \& Hotz-Eakin, 2000; Hout \& Rosen, 2000). With relatively fewer minorities engaging in business ownership (i.e. entrepreneurship), there is less of a chance for a virtuous cycle of business ownership developing through future generations of minority children. In 2013 (SBA, 2015), African Americans represented only 7 percent of business owners while making up 13 percent of the population. Hispanics represented 10.6 percent of business owners with a total population percentage of 17 percent. Of the recognized minority groups in the Unites States, Asians were the only group close on par with the percentage of business owners mirroring the percentage of the population at large (4.3 percent and 4.9 percent respectively).

\section{TABLE 1}

\section{PERCENTAGE OF MINORITY OWNED FIRMS IN THE UNITED STATES, 2002 AND 2007} (IN THOUSANDS)

\begin{tabular}{lccc}
\hline \multicolumn{1}{c}{ Group } & \# of Firms (2002) & \#of Firms (2007) & \% Increase \\
& & & $(2002-2007)$ \\
Native Indian / Alaskan & $201(1 \%)$ & $237(1 \%)$ & 18.0 \\
Asian & $1,104(5 \%)$ & $1,553(6 \%)$ & 40.7 \\
Black / African American & $1,198(5 \%)$ & $1,922(7 \%)$ & 60.4 \\
Hispanic & $1,573(7 \%)$ & $2,260(8 \%)$ & 43.7 \\
Native Hawaiian / Pacific Islander & $29(0 \%)$ & $39(0 \%)$ & 34.5 \\
Minority Summary & $4.105(18 \%)$ & $6,011(22 \%)$ & 46.4 \\
Non-Minority & $18,870(82 \%)$ & $21,099(78 \%)$ & 11.8 \\
Total & $22,975(100 \%)$ & $27,110(100 \%)$ & $18 \%$ \\
\hline
\end{tabular}

(U.S. Census Bureau, Statistical Abstract of the United States, 2012)

The growth of minority entrepreneurs, who provide many jobs and opportunities for economically disadvantaged groups in the U.S., is the focus of this research. Currently, minority entrepreneurs are underrepresented in the US economy. Further, they often underperform compared to non-minority business owners. According to the Small Business Administration, a substantial racial and ethnic gap in organization's earnings persists among entrepreneurs of various racial backgrounds (Blanchflower, 2009; SBA, 2015). While this remains the case, there are some positive trends occurring. Table 1 contains the percentages of minority firms and the percentage of entrepreneurial firm growth in the U.S. from 2002 through 2007. During this period, there was a $60 \%, 44 \%$ and $41 \%$ growth of African American, Hispanic and Asian firms respectively. Relatively, non-minorities had a growth rate of $12 \%$ while the growth rate 
of the entire U.S. was 18\%. Minorities in the Asian, African American, and Hispanic population demonstrated the fastest growth and these trends are expected to continue for the next few decades (U.S. Census Bureau, 2012).

From 2002-2007, minorities accounted for slightly more than six million firms or 5\% of total private sector employment (U.S. Census Bureau, 2012). During the same period, minority entrepreneurs contributed over $\$ 920$ billion to the U.S. economy (U.S. Census Bureau, 2012). Despite generating positive dollars to the U.S. economy, minority businesses are still less likely to survive in comparison to non-minority business owners (Boden \& Headd, 2002; Christopher, 1998; Robb, 2002; Rogers, Gent, Palumbo, \& Wall, 2001).

Minorities often face numerous issues and risks in becoming effective entrepreneurs. These issues are often greater than those faced by non-minority owners. For many minorities who seek to be their own bosses and run their own businesses, the endeavor of entrepreneurship involves considerable risk, hard work, and sacrifice. Numerous issues can stop a person from engaging in self-employment, for example lack of experience, absence of mentors, and insufficient finances. Additional factors that may cause minorities to shy away from business ownership are deficient business skills, poor entrepreneurial backgrounds, and education (Bates, Jackson \& Johnson, 2007; Strom, 2007). The absence of social capital is also a debilitating factor. This study examines the presence of social capital among minority entrepreneurs in Arkansas and its influence on entrepreneurial success.

\section{LITERATURE REVIEW}

An entrepreneur is a person who seeks growth and creation of a new product or service where it did not previously exist (Collins, Hanges, \& Locke, 2004). Kuratko and Hodgetts (2007) describe an entrepreneur as a creator of new ventures and a person who deals with ambiguity in a number of different ways and has the know-how to anticipate risks. Other definitions emphasize the role of opportunity such as the Stevenson and Jarillo (1990) definition that states entrepreneurship is the willingness to act and the process by which people pursue opportunities without regard to resources they currently control.

According to the literature, social capital (Backes-Gellner \& Moog, 2013; Lin, Ensel \& Vaughn, 1981; Nahapiet \& Ghosal, 1998; Portes, 1998) is a major factor that influences the success of minority entrepreneurs. Similarly, Stam, Arzlanian, and Elfring, (2013) found that diversity of entrepreneurs' personal networks will be more likely to positively relate to small and new firm performance. Social networks were also found to be a significant factor affecting minority entrepreneurs in Arkansas (Blanchett, 2018).

The accumulation and activation of social capital has been identified as one of the key factors in successful entrepreneurship (Chuluunbaatar, Ottavial, Luh \& Kung, 2011; Bandiera, Barankay, \& Rasul, 2008; Smith \& Lohrke, 2008). Social Capital is economic and social networks used by people to promote transactions, tradeoffs, and collaborations as a means to produce goods and services for themselves and for a common good (Backes-Gellner \& Moog, 2013; Lin, Ensel \& Vaughn, 1981; Nahapiet \& Ghosal, 1998; Portes, 1998).

Here are several examples and definitions of social networks. Social capital is a resource that links to a network of relationships. Through social networks, entrepreneurs can gain access to such economic resources as investments, loans, and markets (Adler \& Kwon, 2002). Social capital recognizes knowledge and the ability of dealing with people. Other descriptions and illustrations of social capital are:

1. Social capital comprises of an ability to influence business networks, enhance organizational skills, and understand social supports (Ekanem \& Wyer, 2007),

2. Social capital involves the ability to gain advantages and knowledge from networks and organizational memberships (Lin, Ensel \& Vaugh, 1981; Portes, 1998),

3. The social capital outlook encompasses interpersonal skills, collaboration, networking connections, and political skills to develop organizational value (Bouty, 2000; Day, 2000; Felicio, Couto, \& Caiado, 2012), and

4. Social capital including benevolence and the ability to pinpoint business prospects are important resources to build successful and sustainable ventures (Blanchett, 2018). 
Networking is the exchange of information or services among individuals, groups or institutions.

For entrepreneurs, interacting is a process to access information and secure cooperation and trust from others (Cochran, 2010). Other methods of networking are: (a) family and business networks, (b) membership in professional clubs and, (c) close friendships (Cochran, 2010). Networking ability is an important tool which allows entrepreneurs to better leverage affiliations and operate new ventures. In looking at why black-owned businesses fared worse than white-owned firms Fairlie and Robb (2007) found it was partially due to a lack of human and social capital acquired by having worked in a family member's business. In addition to not having opportunity to work in family businesses, the limited opportunity to gain human and social capital through similar industry work experience in general also contributes to the performance differences.

Interpersonal skills focus on dealing with people, improving organizational skills, and understanding social support which impacts entrepreneurship (Ekanem \& Wyer, 2007). Such skills consist of creating relationships amongst individuals to improve teamwork and cooperation which develops organizational value (Bouty, 2000; Day, 2000). Social capital helps leaders work closely with stakeholders such as subordinates, suppliers, chamber of commerce members, and local city officials. Also, the ability or inability to use effective interpersonal skills can make or break minority entrepreneurial success. Similarly, Baron and Markman (2000) argued that the ability to make favorable first impressions, adapt to wide range of social situations, and be persuasive, can influence the quality of social capital and hence contribute to entrepreneurs' success. Thus, it is important to examine the effect of political and social skills aspect of social capital that associates with success of entrepreneurs, especially among minorities, in Arkansas.

The purpose of this paper is to examine those aspects of social capital that contribute to the success of, or more specifically, will apply to, minority entrepreneurs in Arkansas. To be precise, we try to examine two major parts of social capital, i.e. networking skills and political and social skills. Minority entrepreneurs, likewise, need awareness of social capital to improve interactions and inspire collaborations with groups such as chambers of commerce, civic clubs, or church affiliations. Networking skills along with political and social skills are invaluable. They are important factors associated with the success of minority entrepreneurs.

\section{METHODS}

A questionnaire served as the primary vehicle for data collection. The survey instrument was adopted from prior management literature. The survey instrument addressed social capital and entrepreneurial success. The majority of adopted questions are in a 1-5 Likert scale format while others are of short answer design. The questionnaire was reviewed by faculty members in a university's entrepreneurship program and their comments were incorporated.

Qualtrics Survey Software, an online electronic software package, was used to collect data. This research study gathered information from minority entrepreneurs throughout Arkansas over a six week period from March 5 to April 15, 2017. Since there is no statewide database that can identify minority entrepreneurs, the entrepreneurs were contacted by using different types of minority business directories from a variety of sources. A myriad of lists with names and contact information about minority entrepreneurs throughout Arkansas came from state agencies and organizations such as Arkansas Economic Development Commission, Disadvantage Business Enterprise, Arkansas Office of State Procurement, Arkansas Small Business Development Institute, and Institute on Race and Ethnicity. The respondents included some extremely small minority groups or businesses, so some chambers of commerce were contacted to get additional names of minority enterprises.

\section{Participants}

Approximately 250 surveys were electronically submitted to minority entrepreneurs. Another 125 surveys were hand delivered to businesses and entrepreneurs that were located in relatively small and isolated communities. In addition, 150 surveys were given to minority entrepreneurs as they attended 
conferences, workshops, or training sessions throughout Central Arkansas (Saline, Pulaski, and Faulkner counties), Eastern Arkansas (Saint Francis, Chicot and Lee counties) and Northwest Arkansas (Washington and Benton counties). As a result, 287 valid responses were collected for this research.

A univariate study was conducted to assure normality of the demographic variables and success variables. It was found proportions of different ethnic groups in the sample were compatible with the compositions of the ethnic groups in Arkansas. Other demographic distributions will be discussed in the next section of the paper (see Table 2). For social capital, Ferris et al. (2005) acknowledged reliability of six questions. A Cronbach Alpha method was administered to assess the reliability of the two social capital constructs (networking along with political and social skills). Means, standard deviations, and Cronbach alphas are presented in Table 3 of the next section. One of the more important demographic variables, ethnic group, was not used in the study due to the factors of potential sampling bias. It was found that Native Americans had extremely high incomes and the size of their employees were large. We felt that these responses may be aberrational and/or outliers and thus decided not to use this variable in the study. As a result, four demographic variables (gender, age, education, and work experience) and two social capital variables (social networking along with political and social skills) are used as the major independent variables to assess their relationships with success of minority entrepreneurs in the study.

\section{Measures}

Success is a complicated concept and should be considered from multiple aspects and it is appropriate to use multiple measures (Lumpkin \& Dess, 1996; Wiklund \& Shepherd, 2005). To avoid potential instability of small enterprises, all revenues and number of employees were requested for the past three years. An average was used to assume validity and reliability (especially, consistency) of the success measures.

In this study, the success of minority entrepreneurs is measured by two popular objective indicators, i.e. business revenues and the size of establishment. However, since the secondary data is often not available, the respondents provided self-reported information. For minority entrepreneurs, in addition to external success measured by numbers, it is important to include self-assessed success that is more likely to relate to intrinsic success.

Minority business persons may not earn extremely large revenues but are more likely to be content and satisfied with what they have achieved. Moreover, subjective self-assessments are also quite consistent with objective performance data (Dess \& Robinson, 1984). Intrinsic success thus was included in the study as an additional success measurement. Specifically, two questions on the survey addressed the self-assessment. The first question relates to perceived success and the other question is about perceived self-success in the community. High correlation was found between these two scores. To simplify the study, we used an average score for this self-assessed success. In short, three different measures were used to examine both the external and intrinsic success. Distribution and frequencies of dependent variables, revenues, number of employees, and self-assessed scores are presented in Table 4.

A Pearson correlation coefficient matrix was derived to assess the bivariate relationships among all independent and dependent variables (see Table 5). Since there were some strong relationships found between and among the independent variables, both listwise and stepwise regressions were conducted to explore and fine tune the explanation models for different measures of success for minority entrepreneurs (see Tables 6 and 7). A test for multicollinearity of the social capital variables was conducted. Neither exceeded permissible levels.

\section{RESULTS AND FINDINGS}

In Table 2, the demographics information about the gender, age, education, work experience and ethnic group of respondents in the sample is presented. 
TABLE 2

MEAN AND STANDARD DEVIATION FOR DEMOGRAPHIC ANALYSIS

\begin{tabular}{|c|c|c|c|c|}
\hline Variable & $\mathrm{N}$ & $\%$ & Mean & S.D. \\
\hline Gender & & & .42 & .49 \\
\hline Male & 167 & 58.2 & & \\
\hline Female & 119 & 41.5 & & \\
\hline Missing & 1 & .3 & & \\
\hline Total & 287 & 100.0 & & \\
\hline Age & & & 42.26 & 11.75 \\
\hline $21-30$ & 44 & 15.3 & & \\
\hline $31-40$ & 88 & 30.7 & & \\
\hline $41-50$ & 80 & 27.9 & & \\
\hline $51-60$ & 49 & 17.1 & & \\
\hline $61-70$ & 23 & 8.0 & & \\
\hline $71+$ & 1 & .3 & & \\
\hline Missing & 2 & .7 & & \\
\hline Total & 287 & 100.0 & & \\
\hline Education & & & 14.67 & 2.25 \\
\hline Less than High School & 3 & .1 & & \\
\hline High School & 61 & 21.3 & & \\
\hline Certification/Self-Taught & 34 & 11.8 & & \\
\hline \multicolumn{5}{|l|}{ Experience } \\
\hline Associates Degree & 53 & 18.5 & & \\
\hline College/University & 102 & 35.5 & & \\
\hline \multicolumn{5}{|l|}{ Degree } \\
\hline Advanced/Professional & 33 & 11.5 & & \\
\hline \multicolumn{5}{|l|}{ Degree } \\
\hline Missing & 1 & .3 & & \\
\hline Total & 287 & 100.0 & & \\
\hline Experience in Years & & & 12.35 & 9.60 \\
\hline \multirow[t]{2}{*}{0} & 20 & 7.0 & & \\
\hline & 51 & 17.8 & & \\
\hline \multicolumn{5}{|l|}{$1-5$} \\
\hline $6-10$ & 73 & 25.4 & & \\
\hline $11-15$ & 60 & 21.5 & & \\
\hline $16-20$ & 40 & 13.6 & & \\
\hline $21-25$ & 17 & 5.6 & & \\
\hline $26+$ & 26 & 9.1 & & \\
\hline Total & 287 & 100.0 & & \\
\hline \multicolumn{5}{|l|}{ Ethnic Group } \\
\hline African American & 145 & 50.5 & & \\
\hline Hispanic American & 65 & 22.6 & & \\
\hline Asian American & 43 & 15.0 & & \\
\hline American Indian & 19 & 6.6 & & \\
\hline Pacific Islander & 2 & .7 & & \\
\hline Other (Indian, Disabled & 11 & 3.8 & & \\
\hline \multicolumn{5}{|l|}{ Veteran) } \\
\hline Missing & 2 & .7 & & \\
\hline Total & 287 & 100.0 & & \\
\hline
\end{tabular}


Among individuals that participated in the survey 58\% (167) were male and 42\% (119) female, the average score for gender was found to be .42 . About 58 percent of the entrepreneurs were between the ages of 31-50. It was also found that about $17 \%$ of respondents were between the ages of 61 and 70 . Relatively, the sample has a good representation in each age group. The average age for the entrepreneurs was 42 years old. For education, it was found about 33 percent of respondent had high school degrees and/or certificates. About 54 percent or more than half of respondents were found to have an associate degree or a four years college degree. Relatively, minorities in this survey have a good educational background. If we use years of schooling for each category, the average schooling year was found to be 14.67 with a standard deviation of 2.25 .

According to the Arkansas Census (2019), African Americans are the largest ethnic group in Arkansas and was also found to be the largest ethnic group that participated in the survey (about 51 percent). Hispanic Americans were the second largest ethnic group that participated in the survey (about 22.6 percent). Hispanic Americans are the second largest ethnic group in Arkansas according to the census. This study maintains a relatively good representation of different ethnic groups in the survey. As mentioned earlier in the paper, it was found that American Indians had extremely large average revenues and large size companies that were not consistent with the census or national data. It was also found that Native American accounted for $2 \%$ of US population and only $1 \%$ of population in Arkansas. We had a significantly larger size of Native Americans in our sample, i.e. $6.6 \%$. It is very likely that this minority group might distort the results. Therefore, the ethnic group was not used for further analysis. It only demonstrated for the reason of comparing compositions of ethnic groups between the sample and the state.

Social capital was measured in two components, networking along with political and social skills that were generated from six Likert-scale questions. Means and standard deviations of six questions are presented in Table 3. Both Cronbach alphas for each component were greater than .70 which were .80 for networking and .86 , for social and political skills respectively. Each component suggested good internal consistency (Meyers, Gamst, \& Guarino, 2017; Hinkin, 1995, 1998; Pallant, 2016). There is little difference between the means for networking which was 4.46 and political and social skills with a mean score of 4.33 .

TABLE 3

\section{CRONBACH ALPHAS, MEANS, AND STANDARD DEVIATIONS FOR RELIABILITY ANALYSIS ON SOCIAL CAPITAL VARIABLES}

\begin{tabular}{lccc}
\hline Variables & $\alpha$ 's & Means & S.D. \\
\hline Networking & .80 & 4.46 & .54 \\
I spend a lot of time at work developing connections with others. & & 4.36 & .66 \\
When communicating, I try to be genuine in what I say and do. & & 4.60 & .60 \\
It is easy for me to develop good rapport with most people. & & 4.50 & .65 \\
& & & \\
Political and Social Skills & .86 & 4.33 & .66 \\
I am good at building relationships with influential people. & & 4.40 & .69 \\
I know a lot of important people and am well connected. & & 4.22 & .86 \\
I am good at using networks to make things happen. & 4.36 & .75 \\
\hline
\end{tabular}

Success of minority entrepreneurs was measured by three different indicators, i.e. business revenues, size of establishment by number of employees, and a self-assessment measure. 
TABLE 4

FREQUENCIES, MEANS, AND STANDARD DEVIATIONS OF DEPENDENT VARIABLE SUCCESS

\begin{tabular}{lcccc}
\hline Variables & $\mathrm{N}$ & $\%$ & Means & S.D. \\
\hline Revenue & & & $\$ 129,605.60$ & $\$ 128,692.19$ \\
$\$ 1-50,000$ & 87 & 20.2 & & \\
$50,001-100,000$ & 58 & 30.7 & & \\
$100,001-250,000$ & 88 & 8.4 & & \\
$250,001-500,000$ & 24 & 1.7 & & \\
$500,001-1,000,000$ & 5 & 8.7 & & \\
Missing & 25 & 100.0 & \\
Total & 287 & & & \\
& & & & \\
Number of Employees & & 67.9 & \\
$0-5$ & 195 & 22.0 & \\
6-10 & 63 & 8.0 & \\
$11-20$ & 23 & 2.1 & \\
$21-50$ & 6 & 100.0 & \\
Total & 287 & & \\
& & & \\
Self-Assessment & & .3 & \\
$1-1.9$ & 1 & 1.7 & \\
2-2.9 & 5 & 10.5 & \\
3-3.9 & 30 & 85.4 & \\
4 thru highest & 245 & 2.1 & \\
Missing & 6 & 100.0 & \\
Total & 287 & & \\
\hline
\end{tabular}

In Table 4, about 30 percent of respondents were found to make less than $\$ 50,000$ and 20 percent of them make between $\$ 50,000$ and $\$ 100,000$. It appears that revenues for minority entrepreneurs in Arkansas are low. If we use a mid-value for each revenue category, we identified the average annual revenue was $\$ 129,605$ with a standard deviation of $\$ 128,692$. There are some possible reasons which accounted for low revenues. In the original univariate analysis, two millionaires were identified. To avoid outliers and skewness, two millionaires were assigned missing and excluded from this computation.

Therefore, the average income was lower with exclusion of two millionaires. Normally, there are tendencies that self-report revenues or revenues for small business are lower. Since there are not official data available, self-reported three years averages was the best measure for success in revenues. All these are reasons why revenues for minority in Arkansas are relatively low. The average number of the employees was 5.9 with a standard deviation of 0.65. Minority entrepreneurs in Arkansas were more likely to run a family business or a small business. The self-assessed scores for success of entrepreneurs was in a scale of 1-5. The majority of them, i.e. 85 percent, was found to be four to five. The average score of self-assessed score was 4.19 with a standard deviation of .65 (see Table 4).

A Pearson correlation analysis was conducted among demographic variables, two social capital variables as well as three different measures of success. As previously mentioned according to the preliminary analysis, networking and political and social skills are highly correlated with $r=0.63$ (see Table 5). Networking skills are found to be correlated to self-assessed success but not external measures of success. Political and social skills are confirmed to be significant and contributing to all aspects of success of minority entrepreneurs in Arkansas. 
TABLE 5

PEARSON CORRELATION AMONG SOCIAL CAPITAL AND DEPENDENT VARIABLES

\begin{tabular}{lccccccccc}
\hline Variables & 1 & 2 & 3 & 4 & 5 & 6 & 7 & 8 & 9 \\
\hline 1. Age & 1.00 & & & & & & & & \\
2. Gender & $-.19^{* *}$ & 1.00 & & & & & & & \\
3. Education & $.18^{* *}$ & .03 & 1.00 & & & & & & \\
4. Work Experience & $.55^{* *}$ & -.17 & .00 & 1.00 & & & & & \\
5. Networking & .00 & .04 & .97 & .09 & 1.00 & & & & \\
6. Political \& Social & .02 & -.06 & $.16^{* *}$ & $.17^{* *}$ & $.63^{* *}$ & 1.00 & & & \\
$\quad$ Skills & & & & & & & & & \\
7. Revenues & $.20^{* *}$ & $-.14^{*}$ & $.13^{*}$ & $.21^{* *}$ & .04 & $.18^{* *}$ & 1.00 & & \\
8. \# of Employees & .09 & $-.15^{*}$ & -.01 & $.13^{*}$ & .06 & $.17^{* *}$ & $.44^{* *}$ & 1.00 & \\
9. Self-Assessment & .06 & .00 & $.16^{* *}$ & $.16^{* *}$ & $.20^{* *}$ & $.29^{* *}$ & $.21^{* *}$ & $.13^{* *}$ & 1.00 \\
\hline
\end{tabular}

* Indicates significant level of .05

** Indicates significant level of .01

Regarding the demographic variables, it was found that age is negatively related to gender. For gender, because males were coded as zero and females were coded as one, it implies that males are older than females at .01 level of significance. It was also found that age was positively related to education and work experience. People with older age were more likely to have higher education and work experience. Gender was found to have no relationship with education and work experience. Education was also identified as not having a relationship with work experience.

If we evaluate the relationships between demographic background and success of minority entrepreneurs, it found that age, males, education, and work experiences were positively related to revenues for minority entrepreneurs. It means that for those who are older, male, highly educated, and have more work experiences, there was a tendency that they will make more money. For size of employees, only two demographic variables, gender and work experience were found to be important. Specifically, females were more likely to run smaller sized companies. Minorities with more work experience were more likely to run larger sized companies. Intrinsic success or self-assessed success was found to be associated with education and work experience. Minorities with higher education and more work experience are more likely to feel successful.

As presented in the correlation metrics, there are statistically significant relationships among demographic variables and social capital variables. Several regression analyses were thus conducted. In Table 6, a listwise regression analysis that included all independent variables and the three dependent variables are presented. Simplified stepwise regressions that include only significant independent variables were conducted and presented in Table 7. 
TABLE 6

LISTWISE REGRESSION ANALYSIS FOR SOCIAL CAPITAL ON SUCCESS OF MINORITY ENTREPRENEURS

\begin{tabular}{lcccccc}
\hline & \multicolumn{2}{c}{ Revenue } & \multicolumn{2}{c}{ Of Employees } & \multicolumn{2}{c}{ Self-Assessment } \\
Independent Variables & $\mathrm{B}$ & $\mathrm{t}$ & $\beta$ & $\mathrm{t}$ & $\beta$ & $\mathrm{t}$ \\
\hline Constant & -57412.38 & -.69 & 2.74 & .85 & 2.73 & 7.17 \\
Age & 1073.82 & 1.23 & .03 & .87 & -.001 & -.26 \\
Gender & -21274.49 & -1.31 & -1.39 & $2.21^{* *}$ & .06 & .80 \\
Education & 5634.79 & 1.54 & -1.00 & -.70 & .04 & $2.30^{* *}$ \\
Work Experience & 14411.17 & 1.36 & .01 & .30 & .01 & $2.50^{* *}$ \\
Networking & -29550.02 & -1.55 & -.60 & -.79 & -.07 & -.78 \\
Political \& Social Skills & 41665.95 & $2.73^{* *}$ & 1.52 & $2.52^{* *}$ & .26 & $3.63^{* *}$ \\
& & & & & & \\
F-Value & $4.56^{* *}$ & & $2.90^{* *}$ & & $6.67 * *$ & .000 \\
Significance & 0.00 & & .009 & & .13 & \\
R Square & .100 & & .06 & & &
\end{tabular}

The multiple regression identified three separate models. All three models were statistically significant at $\mathrm{p}<.01$. The $\mathrm{R}$ squares range from .06 to .13 (see Table 6). After reviewing information about the parameter $t$ tests, it was found that only political and social skills was statistically significant predictors for revenues. Other demographic or independent variables were not influencers of revenues because of their correlations with political and social skills. For number of employees, two independent variables, gender and political and social skills were statistically significant. For the self-assessed success, there were three significant independent variables, education, work experience, and political and social skills.

TABLE 7

STEPWISE REGRESSION ANALYSIS FOR SOCIAL CAPITAL ON SUCCESS OF MINORITY ENTREPRENEURS

\begin{tabular}{|c|c|c|c|c|c|c|c|c|}
\hline \multirow[b]{2}{*}{ Variable } & \multirow{2}{*}{$\begin{array}{c}\text { Revenue } \\
\beta\end{array}$} & \multicolumn{3}{|c|}{ \# Of Employees } & \multicolumn{4}{|c|}{ Self-Assessment } \\
\hline & & $\mathrm{T}$ & Variables & $\beta$ & $\mathrm{t}$ & Variables & $\beta$ & $\mathrm{t}$ \\
\hline Constant & -28860.2 & -0.56 & Constant & 1.40 & 0.694 & Constant & 2.58 & $8.46^{* *}$ \\
\hline Pol_Soc & 29121.39 & $2.45 * *$ & Pol_Soc & 1.2 & $2.65 * *$ & Pol_Soc & 0.22 & $4.05^{* *}$ \\
\hline \multirow[t]{2}{*}{ Work_Exp } & 2407.06 & $2.84 * *$ & Gender & -1.61 & $-2.65^{* *}$ & Work_Exp & 0.01 & $2.78 * *$ \\
\hline & & & & & & Edu & 0.04 & $2.30 * *$ \\
\hline F-Value & 8.48 & & F-Value & 7.47 & & F-Value & 13.02 & \\
\hline Sig & 0.00 & & Sig & 0.00 & & Sig & 0.00 & \\
\hline R_Square & 0.06 & & R_Square & 0.05 & & R_Square & 0.13 & \\
\hline
\end{tabular}

**Indicates Significance at .01 level

A stepwise regression was applied to streamline the number of significant variables to show the best model (Meyers, Gamst \& Guarino, 2017). In Table 7, all regression models were statistically significant by using $\mathrm{F}$ test with $\mathrm{p}<.00$. They are comparable with listwise regressions presented in Table 6 . If we 
examine stepwise models, it is found that these models can explain from 6 percent (for revenue), to 5 percent (for size of the company), to 13 percent for self-assessed success of the variance of the dependent variables, respectively. Relatively, social capital along with demographic variable do a better job in explaining variance of self-assessed success.

If we take a look at parameter t- test, it is found political and social skills along with work experiences are two important factors for revenues of minority entrepreneurs in Arkansas. For number of employees, two factors, gender and political and social skills were found to be statistically significant. For self-assessed success, in addition to political and social skills, education and work experience were found to be significant. It is clear that political and social skills are consistently significant for all three success measures. Work experience is found to be significant for revenues and self-assessed success. Moreover, gender is statistically significant for the employee size of the company. Males are more likely to run larger size companies than their counter part. Education level is found to be an additional factor that explain self-assessed success.

In sum, it is found that political and social skills are the most important factor that predict success of minorities in Arkansas. Work experience is also an important factor that explains two of the three dependent variables, i.e., revenues and self-assessed success. In addition to political and social skills, gender is another important factor associated with self-assessed success.

\section{DISCUSSION AND RECOMMENDATIONS}

Social networking was a significant and important factor contributing to success of entrepreneurs at new and small companies (Stam et al., 2013; Chuluunbaatar, et al., 2011; Bandiera et al., 2008; Smith \& Lohrke, 2008). Among minorities in Arkansas, according to the correlation analysis and regression analysis, social networking was found to be an important predictor of subjective or intrinsic success. The results imply that minority entrepreneurs feel social networking contributes to their perceived success. But for extrinsic success measures, i.e. revenues and size of employees, no statistical significance it is found among minority entrepreneurs in this study. Possible reasons for the lack of significance are firm age and the business environment of the firm.

According to Lechner Dowling, and Welpe (2006), the network requirements of small firms might change over time. There are different impacts regarding social networking for new firms or old firms. Hence, age of the firm will be important to identify impacts of social networks on a firm's success. Witt (2004) also argued that the stage of the new firm can affect the impact of social networking. The age or stage of the new enterprises could be a reason that affects the impact of social networks for minorities in Arkansas and should be considered in future related studies.

Furthermore, Witt (2004) argued that networking effectiveness may depend on the environmental context of small firms. For instance, networking efficiency may be different for low technology firms compared to high technology firms. Start-up conditions may be different for various industries or business as well. For instance, entrepreneurs may differ largely in such available resources such as financial capital, know-how, patents, or markets. Stam, et al., (2013) found, from their meta-analysis, that both the industry and country level context of small firms are important environmental factors that influence social network effects.

Possible factors that will affect examining social networking's effect on financial success have been addressed in the previous paragraphs. For internal or self-assessed success, the relationship has been confirmed by the correlation analysis. Higher levels of social network contribute to intrinsic success among minority entrepreneurs in Arkansas. However, if we consider both networking and political and social skills in the regression model, the effect of political and social skills is still statistically significant, while the effect of networking is not. The high correlation between networking and political and social skills may be the explanation for this result.

If we look at the second measure that focuses on the social capital skills, i.e., political and social skills, it is found that these skills relate to all three measures of success. It is consistent with most of the previous research (Baron \& Markman, 2000; Davies, Stankov, \& Roberts, 1998). It is true that minorities 
with better political and social skills are more likely to be successful extrinsically or intrinsically. Political and social skills are very important social capital for minority entrepreneurs to become successful in Arkansas. More training in political and social skills provided to minorities in Arkansas will be one of important recommendations we suggest. According to Baron and Markman (2000) social skills can be divided to different areas, social perception, impression management, persuasion and influence, and social adaptability. It is also extensively discussed in Ickes, Weber and Harvey (1994) regarding social relationships. We recommend that it is important to further analyze specific political and social skills that will be useful and significant to minority entrepreneurs.

\section{CONCLUSION}

In summary, social capital has been divided into two areas in this study, social networking and political and social skills. Social networking is found to significantly impact only internal or intrinsic success measure. It is not related to external or extrinsic success among minorities in this study. Possible reasons have been examined and discussed. Political and social skills are found to be statistically important to the success of minority entrepreneurs in Arkansas internally and externally. More resources in developing political and social skills for minorities are suggested. This is a preliminary study which examines social capital and success of minority entrepreneurs. More research with more specific and refined measures in social capital and success of minorities is also recommended. 


\section{REFERENCES}

Adler, P. S., \& Kwon, S. W. (2002). Social capital: Prospects for a new concept. Academy of Management Review, 27(1), 17-40.

Arthur, S. J., \& Hisrich, R. D. (2011). Entrepreneurship through the ages: Lessons learned. Journal of Enterprising Culture, 19(1), 1-40. doi: 10.1142/S0218495811000696.

Backes-Gellner, U., \& Moog, P. (2013). The disposition to become an entrepreneur and the jacks-of-alltrades in social and human capital. The Journal of Socio-Economics, 47, 55-72.

Bandiera, O., Barankay, I., \& Rasul, I. (2008). Social capital in the workplace: Evidence on its formation and consequences. Labour Economics, 15(4), 724-748.

Baron, R. A., \& Markman, G. D. (2000). Beyond social capital: How social skills can enhance entrepreneurs' success. Academy of Management Perspectives, 14(1), 106-116.

Bates, T., Jackson, W. E., \& Johnson, J. H. (2007). Introduction: Advancing research on minority entrepreneurship. The Annals of the American Academy of Political and Social Science, 613(1), $10-17$.

Blanchett, M. A. (2018). Factors contributing to success of minority entrepreneurs in Arkansas (Order No. 13421962). Available from ProQuest Dissertations \& Theses Global. (2187147014). Retrieved from https://search.proquest.com/docview/2187147014?accountid=10017

Blanchflower, D. G. (2009). Minority self-employment in the United States and the impact of affirmative action programs. Annals of Finance, 5(3-4), 361-396. doi:10.1007/s10436-008-0099-1

Boden, R. J., \& Headd, B. (2002). Race and gender differences in business ownership and business turnover. Business Economics, 37(4), 61-72.

Bouty, I. (2000). Interpersonal and interaction influences on informal resource exchanges between R\&D researchers across organizational boundaries. Academy of Management Journal, 43, 50-65.

Chuluunbaatar, E., Ottavia, D., Luh, D-B., \& Kung, S-F. (2011). The entrepreneurial start-process: The role of social capital and the social economic condition. Asian Academy of Management Journal, 16(1), 43-71.

Christopher, J. E. (1998). Minority business formation and survival: Evidence on business performance and viability. The Review of Black Political Economy, 26(1), 37-72.

Cochran, P. (2010). African American entrepreneurial venues and social capital. Journal of Developmental Entrepreneurship, 15(3), 287-300.

Collins, C. J., Hanges, P., \& Locke, E. A. (2004). The relationship of need for achievement to entrepreneurship: A meta-analysis. Human Performance, 17(1), 95-117.

Davies, M., Stankov, L., \& Roberts, R. (1998) Emotional Intelligence: In Search of an Elusive Construct. Journal of Personality and Social Psychology, 75, 989-1015. http://dx.doi.org/10.1037/00223514.75.4.989

Day, D.V. (2000). Leadership development: A review in context. Leadership Quarterly, 11, 581-613.

Decker, R., Haltiwanger, J., Jarmin, R., \& Miranda, J. (2014). The role of entrepreneurship in US job creation and economic dynamism. The Journal of Economic Perspectives, 28(3), 3-24.

Dess, G. G., \& Robinson, R. B. (1984). Measuring organizational performance in the absence of objective measures: The case of the privately held firm and conglomerate business unit. Strategic Management Journal, 5(3), 265-273.

Dunn, T. A., \& Holtz-Eakin, D. J. (2000). Financial capital, human capital, and the transition to selfemployment: Evidence from intergenerational links. Journal of Labor Economics, 18(2), 282305.

Ekanem, I., \& Wyer, P. (2007). A fresh start and the learning experience of ethnic minority entrepreneurs. International Journal of Consumer Studies, 31, 144-151.

Fairlie, R.W., \& Robb, A. M. (2007). Why are black owned businesses less successful than white owned businesses? The role of families, inheritances, and business human capital. Journal of Labor Economics, 25(2), 289-323. 
Felicio, J., Couto, E., \& Caiado, J. (2012). Human capital and social capital in entrepreneurs and managers of small and medium enterprises. Journal of Business Economics and Management, 13(3), 395-420.

Ferris, G. R., Treadway, D. C., Kolodinsky, R.W., Hochwater, W. A., Kacmar, C.J., Douglas, C., \& Frink, D. D. (2005). Development and validation of the political skill inventory. Journal of Management, 31(1), 126-152.

Haltiwanger, J., Jarmin R., \& Miranda J. (2013). Who creates jobs? Small versus large versus young. The Review of Economics and Statistics, 95(2), 347-361.

Hinkin, T. R. (1995). A review of scale development practices in the study of organizations. Journal of Management, 21(5), 967-988.

Hinkin, T. R. (1998). A brief tutorial on the development of measures for use in survey questionnaires. Organizational Research Methods, 1(1), 104-121.

Hout, M., \& Rosen H. S. 2000. Self-employment, family background, and race. Journal of Human Resources, 35(4), 670-692.

Ickes, W., Weber, A., \& Harvey, J. (1994). Methods of studying close relationships. Perspectives on Close Relationships, 18-44.

Kuratko, D. F., \& Hodgetts, R. M. (2007). Entrepreneurship: Theory, Process, Practice. Mason, OH: Thomson/Southwestern.

Lechner, C., Dowling, M., \& Welpe, I. (2006). Firm networks and firm development: The role of the relational mix. Journal of Business Venturing, 21(4), 514-540.

Lentz, B. \& Laband, D. (1990). Entrepreneurial success and occupational inheritance among proprietors. Canadian Journal of Economics, 23(3), 563-79.

Lin, N., Ensel, W., \& Vaughn, J. (1981). Social resources and strength of ties: Structural factors in occupational status attainment. American Sociological Review, 46(4), 393-405.

Lumpkin, G.T., \& Dess, G. G. (1996). Clarifying the entrepreneurial orientation construct and linking it to performance. Academy of Management Review, 21(1), 135-172.

Meyers, L.S., Gamst, G., \& Guarino, A. J. (2017). Applied multivariate research: design and interpretation. Thousand Oaks, CA: Sage.

Nahapiet, J., \& Ghoshal, S. (1998). Social capital, intellectual capital, and the organizational advantage. Academy of Management Review, 23(2), 242-266.

Ortiz-Walters, R., \& Gius, M. (2012). Performance of newly-formed micro firms: The role of capital financing in minority-owned enterprises. Journal of Developmental Entrepreneurship, 17(3). doi: 12500141-125001422

Pallant, J. (2016). SPSS survival manual. Berkshire, England: McGraw-Hill Education. Portes, A. (1998). Social capital. Annual Review of Sociology, 23, 1-24.

Robb, A. M. (2002). Entrepreneurial performance by women and minorities: The case of new firms. Journal of Developmental Entrepreneurship, 7(4), 383-397.

Rogers, C. D., Gent, M. J., Palumbo, G. M., \& Wall, R. A. (2001). Understanding the growth and viability of inner city businesses. Journal of Developmental Entrepreneurship, 6(3), 237-254.

SBA, Office of Advocacy. (2015). Demographic Characteristics of Business Owners and Employees: 2013. Issue Brief Number 6. Retrieved December 15, 2015, from https://www.sba.gov/advocacy/issue-briefs

Smith, D. A., \& Lohrke, F. T. (2008). Entrepreneurial network development: Trusting in the process. Journal of Business Research, 61(4), 315-322.

Stevenson, H., \& Jarillo, J. (1990). A paradigm of entrepreneurship: entrepreneurial management. Strategic Management Journal, 11, 17-27.

Stam, W., Arzlanian, S., \& Elfring, T. (2014). Social capital of entrepreneurs and small firm performance: A meta-analysis of contextual and methodological moderators. Journal of Business Venturing, 29(1), 152-173.

Strom, R. D. (2007). Fostering research on minority entrepreneurship. The Annals of the American Academy of Political and Social Science, 613(1), 6-9. 
U.S. Census Bureau. (2012). Retrieved March 23, 2019, from https://www.census.gov/quickfacts/fact/table/ar/PST045217\#PST045217

U.S. Census Bureau. (2012). Statistics about Business Size (Including Small Business) from the U.S. Census Bureau. Retrieved from www.census.gov/epcd/www/smallbus.html

U.S. Census Bureau. (2019). Quick Facts: Arkansas from the U.S. Census Bureau.

Wennekers, S., \& Thurik, R. (1999). Linking entrepreneurship and economic growth. Small Business Economics, 13, 27-55.

Wiklund, J., \& Shepherd, D. A. (2005). Entrepreneurial orientation and small business performance: A configurational approach. Journal of Business Venturing, 20(1), 71-91.

Witt, P. (2004). Entrepreneurs' networks and the success of start-ups. Entrepreneurship \& Regional Development, 16(5), 391-412.

Zoltan, A., Sameeksha, D., \& Jolanda H. (2008). Entrepreneurship, economic development and institutions. Small Business Economics, 31, 219-234. 